\title{
Public Relations in State Government: A Typology of Management Styles
}

\author{
Grunig model fits \\ 12 state agencies \\ in Louisiana.
}

- Public relations, undoubtedly oversimplified but certainly reduced to its bare essence, is "the management of communication between an organization and its publics."'

Two aspects of public relations identified in that definition-communication and publics-have been the subjects of a substantial body of research in public relations. Most of this research has examined the effect of communication on publics, but a few studies also have examined the behavior of publics. Very few researchers, however, have systematically tried to explain why organizations practice public relations as they do-the management aspect of public relations. Are there models of public relations behavior which seem to "fit" the way certain types of organizations communicate with important constituencies under the rubric of public relations? If so, which organizational characteristics serve as indicators to an organization of an appropriate model of public relations behavior, or serve as predictors of an organization's public relations management style?

- Judy VanSlyke Turk is a journalism faculty member at the University of Oklahoma. She is investigating the research questions suggested in the "conclusions" section of this article as part of her dissertation for the doctorate in public administration from the Maxwell School of Citizenship and Public Affairs. Syracuse University. She wishes to acknowledge with appreciation the cooperation of the Louisiana state agencies which participated in this preliminary study and which have agreed to cooperate further with her dissertation research

\section{A Look at the Literature}

Grunig conceptualized four models of public relations behavior in organizations: press agentry/publicity (a one-way asymmetric model); public information (a oneway symmetric model); two-way asymmetric and two-way symmetric. ${ }^{2}$ He theorized that organizations might practice all four models, but that one model would be dominant. Organizations discriminated among the four models as shown in Figure I.

When the four models were tested on a purposive sample of 16 organizations, the press agentry/publicity model was most common, followed by the two-way asymmetric model. The public information model was least common. Organizations practiced one model more than others, but most combined two or more models, with most including some degree of press agentry/publicity public relations in their behavior. ${ }^{3}$

Grunig concluded there were four independent variables which helped explain when and why organizations practice one or more of the model sets of public relations behaviors. ${ }^{4}$ Two independent variables-scale of demand and knowledge complexity-Grunig called the product! service environment of an organization. Scale and knowledge complexity can interact along their various dimensions, resulting in a four-way typology of organizations based on their product/service en-

I James E. Grunig and Todd Hunt, Managing Public Relations (New York: Holt, Rinehart and Winston), p. 6.

2 Ibid., Chapter 2.

3 James E. Grunig, "Organizations, Environments and Models of Public Relations." Unpublished paper presented to the Public Relations Division, Association for Education in Journalism and Mass Communication, Corvallis, Oregon, August 1983.

Ibid. 
FIGURE I

Characteristics of Four Models of Public Relations

\begin{tabular}{|c|c|c|c|c|}
\hline \multirow[b]{2}{*}{ Characteristic } & \multicolumn{4}{|c|}{ Model } \\
\hline & $\begin{array}{l}\text { Press Agentry/ } \\
\text { Publicity }\end{array}$ & $\begin{array}{c}\text { Public } \\
\text { Information }\end{array}$ & $\begin{array}{l}\text { Two-Way } \\
\text { Asymmetric }\end{array}$ & $\begin{array}{l}\text { Two-Way } \\
\text { Symmetric }\end{array}$ \\
\hline Purpose & Propaganda & $\begin{array}{l}\text { Dissemination } \\
\text { of Information }\end{array}$ & $\begin{array}{l}\text { Scientific } \\
\text { Persuasion }\end{array}$ & $\begin{array}{c}\text { Mutual } \\
\text { Understanding }\end{array}$ \\
\hline $\begin{array}{l}\text { Organizational } \\
\text { Goal }\end{array}$ & $\begin{array}{c}\text { Environmental } \\
\text { Control/ } \\
\text { Domination }\end{array}$ & $\begin{array}{l}\text { Environmental } \\
\text { Adaptation/ } \\
\text { Cooperation }\end{array}$ & $\begin{array}{c}\text { Environmental } \\
\text { Control } \\
\text { Domination }\end{array}$ & $\begin{array}{c}\text { Environmental } \\
\text { Adaptation/ } \\
\text { Cooperation }\end{array}$ \\
\hline $\begin{array}{l}\text { PR Contribution } \\
\text { to Goal }\end{array}$ & Advocacy & $\begin{array}{l}\text { Dissemination } \\
\text { of Information }\end{array}$ & Advocacy & Mediation \\
\hline $\begin{array}{l}\text { Nature of } \\
\text { Communication }\end{array}$ & $\begin{array}{l}\text { One-Way, } \\
\text { Complete Truth } \\
\text { Not Essential }\end{array}$ & $\begin{array}{c}\text { One-Way, } \\
\text { Truth } \\
\text { Important }\end{array}$ & $\begin{array}{l}\text { Two-Way, } \\
\text { Imbalanced } \\
\text { Effects }\end{array}$ & $\begin{array}{c}\text { Two-Way } \\
\text { Balanced } \\
\text { Effects }\end{array}$ \\
\hline $\begin{array}{l}\text { Communication } \\
\text { Model }\end{array}$ & Source--->Rec. & Source--->Rec. & $\begin{array}{c}\text { Source--->Rec. } \\
<-- \\
\text { Feedback }\end{array}$ & $\begin{array}{c}\text { Group---> Group } \\
--\end{array}$ \\
\hline $\begin{array}{l}\text { Nature of } \\
\text { Research }\end{array}$ & $\begin{array}{l}\text { Little; } \\
\text { "Counting } \\
\text { House" }\end{array}$ & $\begin{array}{c}\text { Little: } \\
\text { Readability, } \\
\text { Readership }\end{array}$ & $\begin{array}{l}\text { Formative, } \\
\text { Evaluative } \\
\text { of Attitudes }\end{array}$ & $\begin{array}{c}\text { Formative, } \\
\text { Evaluative of } \\
\text { Understanding }\end{array}$ \\
\hline $\begin{array}{l}\text { Leading } \\
\text { Historical } \\
\text { Figures }\end{array}$ & $\begin{array}{l}\text { P. T. } \\
\text { Barnum }\end{array}$ & $\begin{array}{l}\text { lvy } \\
\text { Lee }\end{array}$ & $\begin{array}{c}\text { Edward L. } \\
\text { Bernays }\end{array}$ & $\begin{array}{c}\text { Bernays, } \\
\text { Educators, } \\
\text { Prof. Leaders }\end{array}$ \\
\hline $\begin{array}{l}\text { Where } \\
\text { Practiced } \\
\text { Today }\end{array}$ & $\begin{array}{l}\text { Sports, } \\
\text { Theatre, } \\
\text { Product } \\
\text { Promotion }\end{array}$ & $\begin{array}{l}\text { Government, } \\
\text { Non-profit, } \\
\text { Associations. } \\
\text { Business }\end{array}$ & $\begin{array}{c}\text { Competitive } \\
\text { Business, } \\
\text { Agencies }\end{array}$ & $\begin{array}{l}\text { Regulated } \\
\text { Business, } \\
\text { Agencies }\end{array}$ \\
\hline
\end{tabular}

Source: Adapted from Grunig and Hunt.

vironment: the traditional organization, the mechanistic organization, the organic organization or the mixed mechanistic/ organic organization (See Figure 2).

Variables of environmental constraints and uncertainty Grunig called the political/regulatory environment. Environmental constraints, one of the variables in the political/regulatory environment, explains whether public relations communication is symmetrical or asymmetrical-whether it balances the public interest with organizational interest or not. The other political/ regulatory variable, environmental uncertainty, explains whether the communication is one-way or two-way. Three levels of constraint-low, medium and highand two levels of uncertainty-low and s. Ihid.

high-become a typology of six political/ regulatory models of behavior that explain why organizations practice each of the four Grunig models (See Figure 3).

Further exploratory research with 14 private-sector organizations and later with federal government agencies confirmed Grunig's conclusions and lent additional support to his four-model, two-environment conceptualization of public relations behavior. ${ }^{5}$

\section{Research Questions in this Study}

The research on which this paper reports is another attempt to verify the appropriateness of Grunig's models to describing and predicting current public relations practices. The universe for this study was one not before examined under 


\section{FIGURE 2}

Typology of Four Organizations, Based on Product/Service Environment. And Hypothesized Model of

Public Relations Practiced by Each

Scale of Demand and Production

Knowledge

Complexity Small Large

$\begin{array}{lll}\text { Low } & \begin{array}{l}\text { Traditional } \\ \text { Organization } \\ \text { (Press Agentry/ } \\ \text { Publicity Model) }\end{array} & \begin{array}{l}\text { Mechanistic } \\ \text { Organization } \\ \text { (Public Informa- } \\ \text { tion Model) }\end{array} \\ \text { High } & \begin{array}{l}\text { Organic Organi- } \\ \text { zation (Two-way } \\ \text { Symmetric } \\ \text { Model) }\end{array} & \begin{array}{l}\text { Mixed } \\ \text { Mechanistic } \\ \text { Organic } \\ \text { Organization } \\ \text { (Mixed Two- } \\ \text { Way Asymmet- } \\ \text { ric/Symmetric } \\ \text { Model) }\end{array}\end{array}$

Grunig's models, namely agencies of a state government.

Hypotheses tested were:

H1: Organizations for which the press agentry/publicity model of public relations is dominant are traditional organizations characterized by small-scale demand and production, low knowledge complexity, an extreme level of environmental constraints (either very low or very high) and low environmental uncertainty.

H2: Organizations for which the public information model of public relations is dominant are mechanistic organizations characterized by large-scale demand and production, low knowledge complexity, medium levels of environmental constraint and low environmental uncertainty.
H3: Organizations for which the twoway asymmetric model of public relations is dominant are mixed mechanistic organizations characterized by large-scale demand and production, high knowledge complexity, an extreme level of environmental constraints (either very low or very high) and high environmental uncertainty.

H4: Organizations for which the twoway symmetric model of public relations is dominant are organic organizations characterized by small-scale demand and production, high knowled ge complexity, medium levels of environmental constraint and high environmental uncertainty.

\section{Method}

All cabinet-level departments in Louisiana which employ disignated public relations/public information representatives were invited to participate in the study, a sample of 17. Departments which did not formally recognize a public relations function or public relations personnel were excluded on the basis that their communication with the public would not be managed but would be instead haphazard, thus not fitting Grunig and Hunt's definition of public relations as "managed" communication.

A 27-item questionnaire-the same questionnaire used by Grunig in his testing of his models-was administered to the highest-ranking management-level public relations/public information specialist in each of these state departments. The public relations/public information managers were asked to rate their agency's public relations behavior by indicating the extent to which each item on the questionnaire

\section{FIGURE 3}

Typology of Public Relations Models

Based on the Political/Regulatory Environment

$$
\text { Extent of Environmental Constraints }
$$

Environmenta! Uncertainty

\section{Low}

High

\begin{tabular}{lll}
\multicolumn{1}{c}{ Low } & \multicolumn{1}{c}{ Medium } & \multicolumn{1}{c}{ High } \\
Press Agentry/ & Public & Press Agentry/ \\
Publicity & Information & Publicity \\
Two-Way & Tvio-Way & Two-Way \\
Asymmetric & Symmetric & Asymmetric
\end{tabular}


corresponded with the reality, not the ideal, of how public relations was practiced in their state departments. 6

Seven of the 27 statements on the questionnaire comprised an index which described public relations behavior that would "fit" the press agentry/publicity model: for instance, "The purpose of public relations in this organization is to promote the organization, its products and services in any way possible." Seven statements, such as "Our media philosophy is to disseminate accurate information to the media but not to volunteer information that is unfavorable to the organization," described behavior that would "fit" the public information model. Six statements described two-way asymmetric model behavior, and six described behavior that would conform to the twoway symmetric model. For example, one of the two-way asymmetric statements was: "The purpose of public relations in this organization is to persuade the public to agree with the organization's point of view." Typical of two-way symmetric statements was: "The purpose of public relations in this organization is to develop mutual understanding between the management of the organization and publics the organization affects." Some statements were included in two indices-such as items on control or adaptation as organizational goals, one-way or two-way communication, and advocacy as a public relations objective-but no index shared more than two items.

Five departments declined to complete the questionnaire, for a final response of completed questionnaires from 12 agencies. Departments which participated were Health and Human Resources, Labor, Corrections, Agriculture, Wildlife and Fisheries, State, Public Safety, Justice, Revenue and Taxation, Commerce and Industry, Education and the Governor's Office.

\footnotetext{
- Meticulous in-depih study of each department's public relations operation over a lengthy time period, used as a check on whether public relations managers reported what really went on in their departments rather than what they wished could happen, would substantially improve the validity of these managers' selfreporting on questionnaire items. Such in-depth study, while highly desirable. was not feasible within the budgetary and time constraints of this particular study, but would prove a fruitful area of future inquiry.
}

Item-by-item "scores" were possible for each agency, since respondents used a fivepoint Likert-type scale, with 5 being high agreement and 1 being high disagreement with each item in terms of its applicability to their agencies' public relations behavior. Mean scores and standard deviations also were computed for each multiple-item index corresponding to the particular public relations models being studied (See Tables 1-4).

Interviews were conducted with these same departmental public information/public relations representatives to determine each department's product-service environment and political/regulatory environment. Those assessments were used in determining "fit" of model to organization in the discussion of study findings (See Figure 4.)

\section{Study Results}

Press Agentry/ Publicity Model Dominant. The press agentry/publicity model was the dominant, most-applicable and best-descriptive model of public relations for only one of the state agencies, the Department of Revenue and Taxation. The department scored 3.29 on the 5-point index used to measure behaviors and fit the press agentry/publicity model, its highest score for any of the four models.

For five agencies-the Departments of State, Agriculture, Health and Human Resources, Commerce and Industry, and Education-this model was subordinate, ranking second of the four models in use.

Mean score for all agencies on the questionnaire items which measured use of this model was 2.80 , lowest mean of any of the four models, indicating this model was least common to state agencies. But $83 \%$ of the agencies scored above the midpoint of 2.50 , and standard deviation was .14, the lowest among the four models.

Grunig's research indicated that organizations for which the press agentry/publicity model is dominant would be organizations facing small, stable demand and little competition for their simple products and services. These organizations also would be low in complexity, small in scale, low in 
308

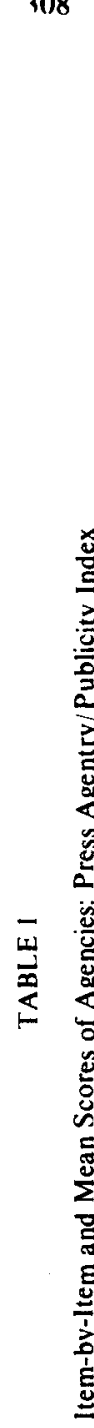

JOURNALISM QUARTERLY
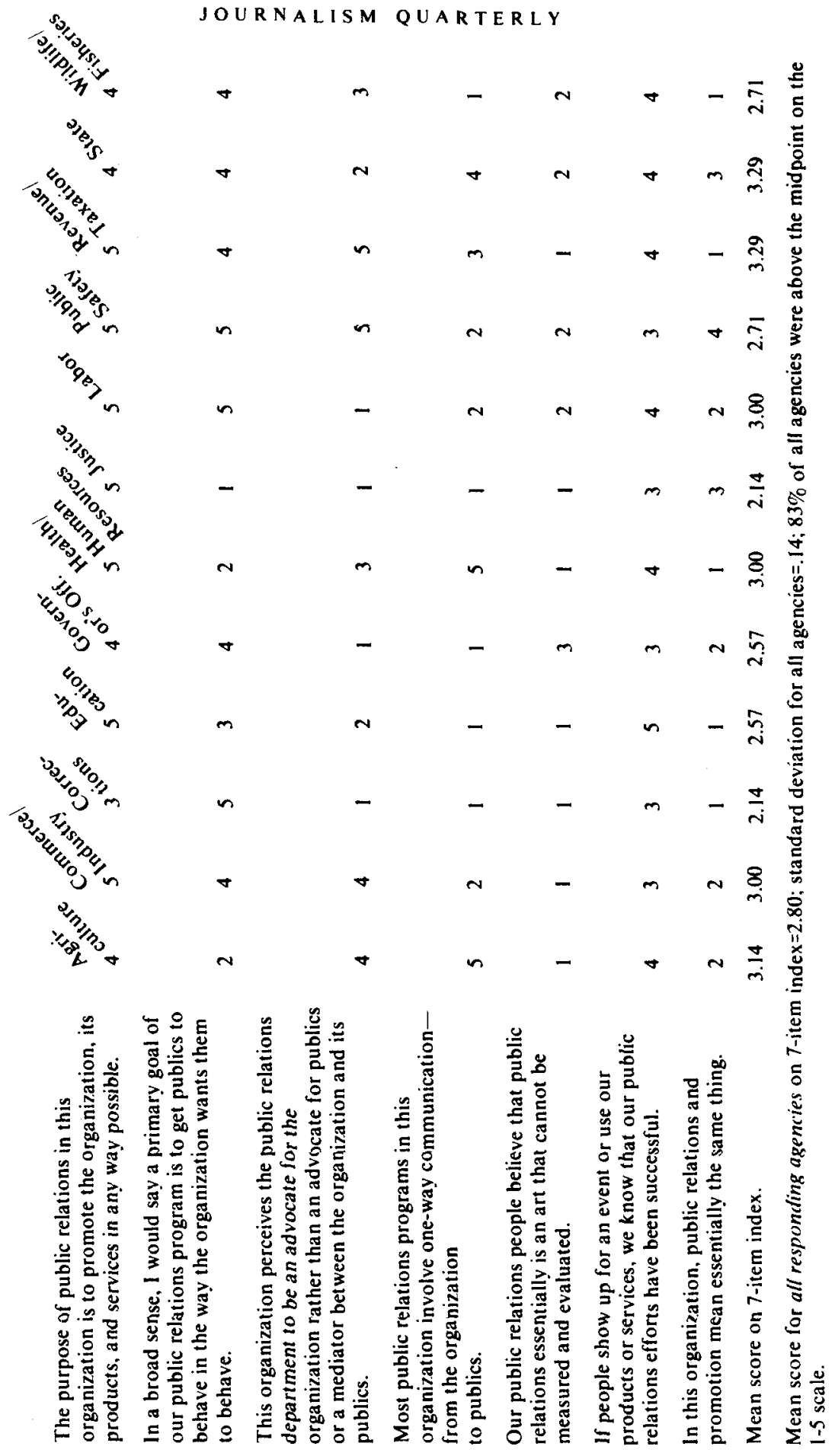
Public Relations in State Government

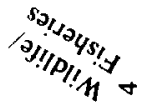
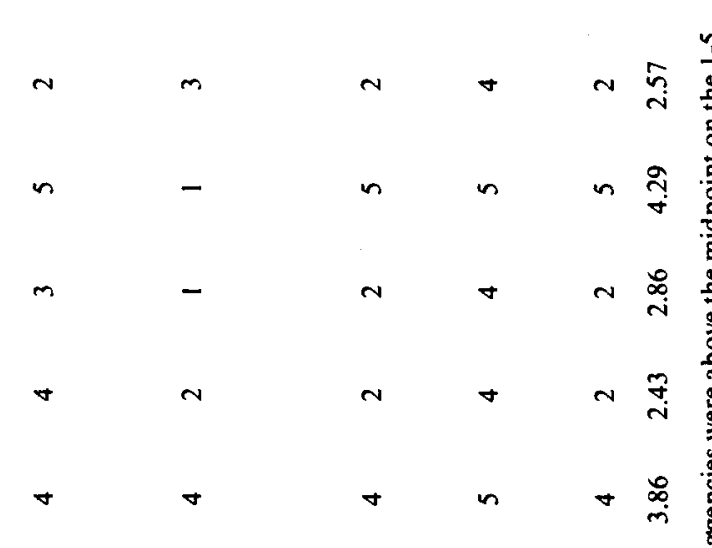

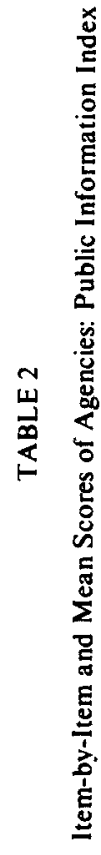

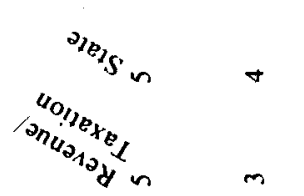

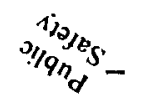

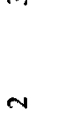<smiles>[3H][Pb]=[18O]</smiles> 


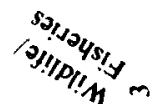

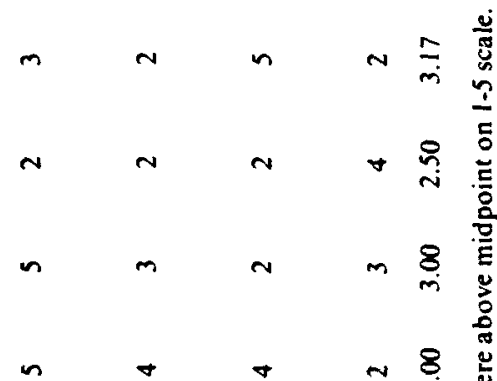

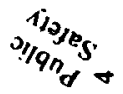

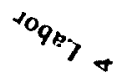

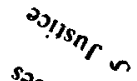<smiles>c1ccc2ccccc2c1</smiles>
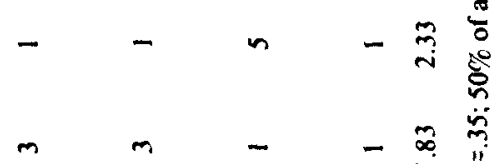

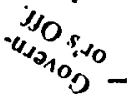

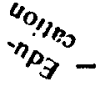<smiles>C[As]1CC[C@H]2CC[C@H]1C2</smiles>

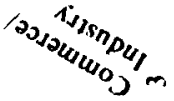

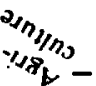

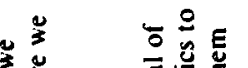

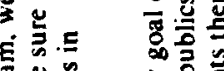

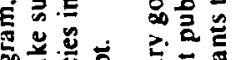

总总焉焉

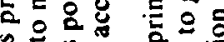

क

$\rightarrow$ a

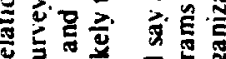

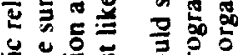

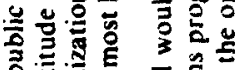

ล 三 늘

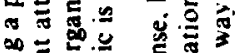

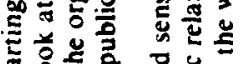

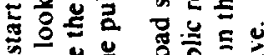

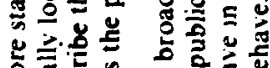

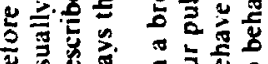
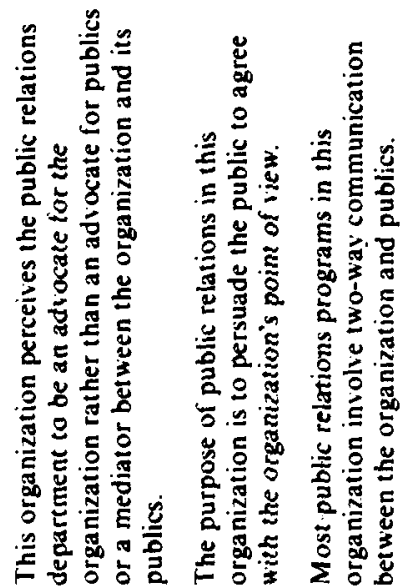

そ.ำ 
Public Relations in State Government

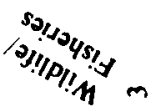

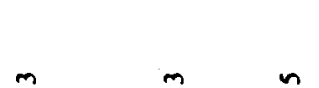

$+\infty \frac{n}{q}$

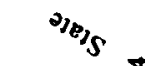<smiles>[AlH2]</smiles>

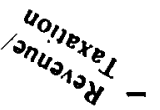

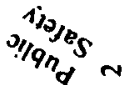
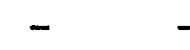

总

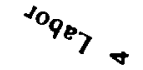
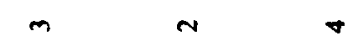

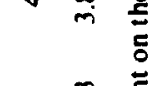

$\sim \stackrel{\sim}{\sim}$

$\sim \stackrel{\text { ก }}{2}$

$\sim \stackrel{\infty}{\sim}$

n $\stackrel{\wp}{+}$

$-5 \stackrel{\frac{\pi}{\pi}}{\pi}$

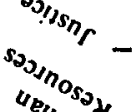<smiles>c1ccccc1</smiles><smiles>C1CCCCC1</smiles>

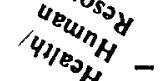

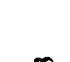

-

"on
$n p_{3}-$

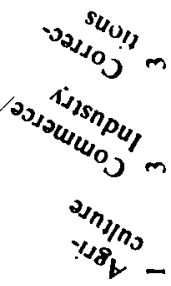

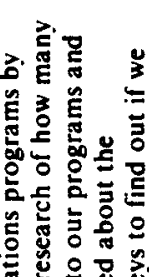

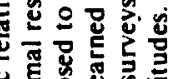

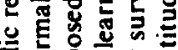

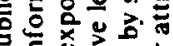

a.t.

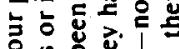

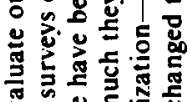
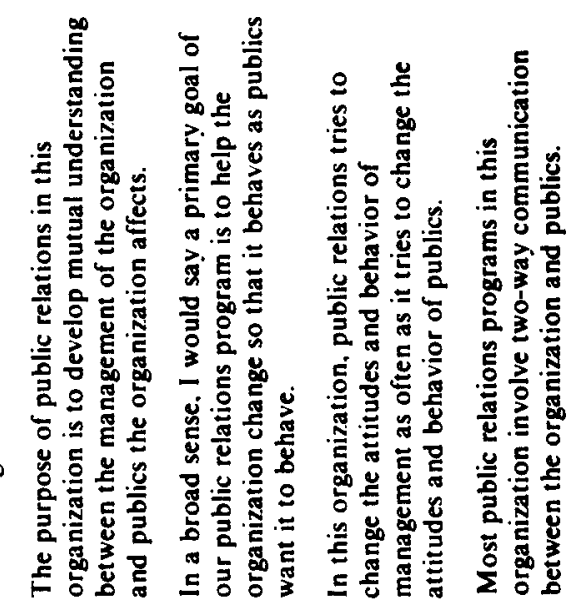

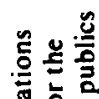

密递它

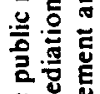

电

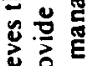

․ㅡ

훙응

등웡 尝

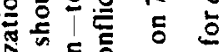

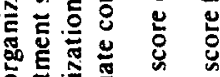

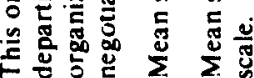




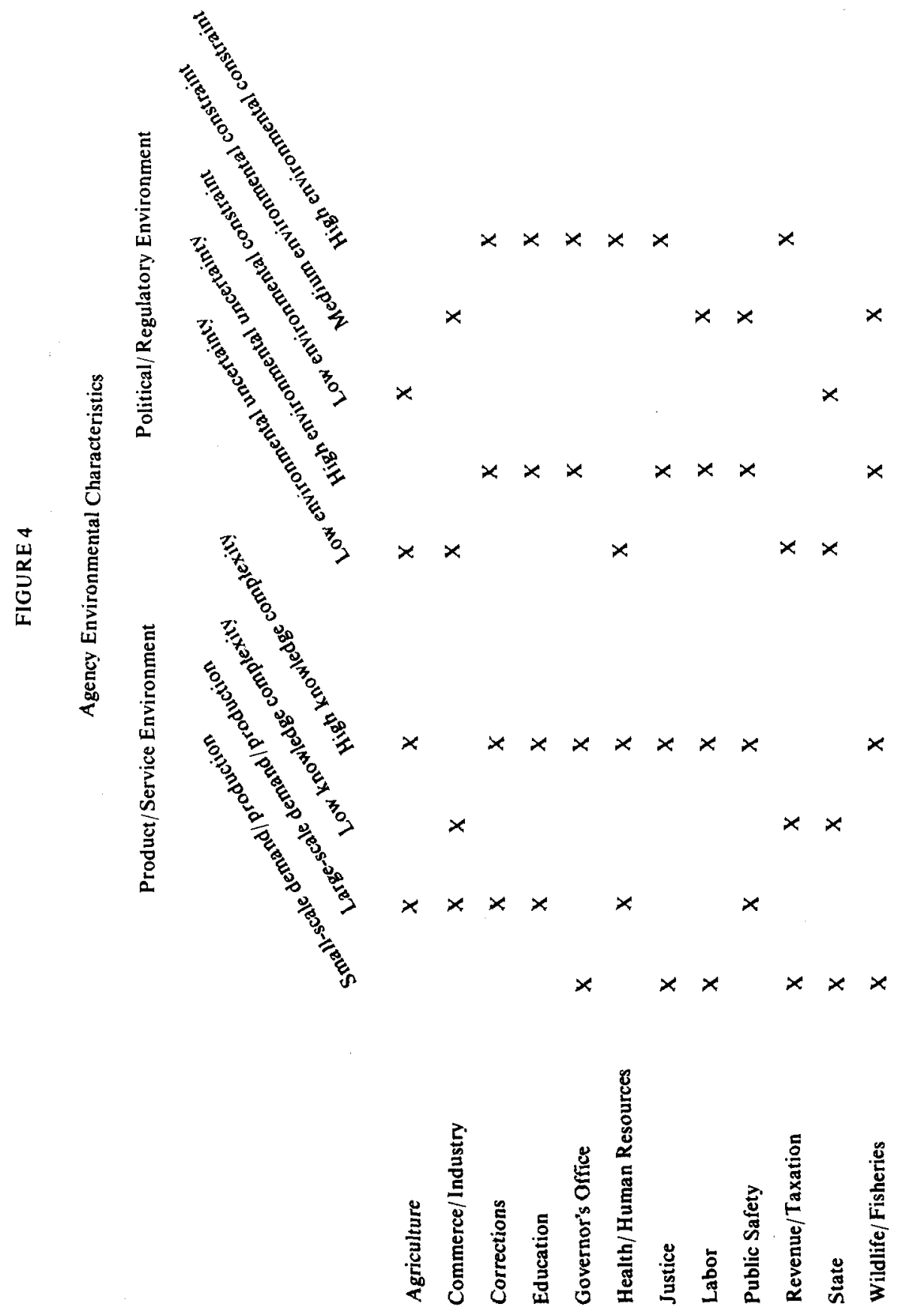


environmental uncertainty and either low or high in environmental constraints.

The Department of Revenue and Taxation fits parts of this description, for by its own admission it faces no competition in its primary service area of levying and collecting tax monies for the state. And depending upon how one defines "small" in the context of demand, the department may also share that characteristic, for tax collectors' services are really not wanted at all by those from whom the money is collected. The characteristic of low environmental uncertainty also seems to fit this department, for the department knows exactly what taxes it will levy and thus the sources of the revenue it will collect because those amounts are pre-determined for the department by legislative action, not changed day to day on a management whim. Because of this legislative determination of many of its functions, however, the department operates under conditions of high (and binding legal) constraints.

Public Information Model Dominant. The public information model was dominant for four state agencies: the Departments of State, Agriculture, Health and Human Resources, and Commerce and Industry. Each of these agencies was likely to approach its public relations activities more from a public information perspective than from the perspective of any other model. On a 5-point scale, the Department of State scored 4.29, Agriculture 4.14, Health and Human Resources 3.86, and Commerce and Industry 3.29.

For three departments-Justice, Labor and the Governor's Office-the public information model was subordinate, ranking second most applicable among the four models in describing the agency's management of public relations activities.

The mean score of all agencies on the public information model was 3.13, highest of any of the four models, indicating it is the model most common among these agencies. Of the agencies surveyed, $83 \%$ scored above the midpoint of 2.5 on the 5 -point scale used to measure public information model behaviors. The standard deviation was a rather large .51 .

Organizations most likely to practice this model of public relations behavior, according to Grunig, operate on a large scale with low complexity and face a low level of environmental uncertainty and a medium level of environmental constraints. Some, but not all, of these characteristics apply to the public informationdominant state agencies.

The Departments of Health and Human Resources, Agriculture and Commerce and Industry were characterized by their public information representatives as largescale organizations, with many divisions and subdivisions, multiple hierarchical levels and a high degree of formalization. But those characteristics apply only marginally to the Department of State.

The services of the Department of Health and Human Resources are complex, for this agency administers a myriad of programs and benefits ranging from welfare to mental health and nursing home licensing, and beneficiaries of the services must meet complicated and stringent eligibility requirements. Likewise, the Department of Agriculture is a maze of services ranging from fertilizer registration to periodic inspection of retail weights and measures, an indication of complexity. The other two agencies for whom this model was dominant exhibit this characteristic of complexity to a lesser extent.

All four agencies say they operate in an environment of relatively low uncertainty, primarily because as arms of state government they operate within the policymaking framework of a state constitution and state law which really leaves only implementation decisions to the agency. Three of the four are not particularly "political" agencies and thus operate with only a moderate level of environmental constraint. With the exception of the Department of Health and Human Resources, the public information model state agencies are not subject to great opposition or pressure from outsiders. Perhaps this is because they are not particularly client-centered (again with the exception of the Department of Health and Human Resources).

Two-Way Asymmetric Model Dominant. The two-way asymmetric model of 
public relations behavior was dominant within two agencies-the Department of Public Safety, with a score of 4.0 on the 5-point scale, and the Department of Corrections, which had a score of 3.33. This model was subordinate, or second-mostapplicable, to the Departments of Revenue and Taxation, and Wildlife and Fisheries.

Mean score for all agencies on index items relating to the two-way asymmetric model was 2.82 , and half $(50 \%)$ of the agencies in the sample scored above the midpoint for the model. Standard deviation was . 35 .

High product/service complexity, large scale, high environmental uncertainty and an extreme-either high or low-level of environmental constraints characterize twoway asymmetric organizations, according to Grunig. Those characteristics seem to fit both the public safety and corrections agencies which have similar missions and concerns at opposite ends of the law enforcement spectrum.

The corrections department, with responsibility for overseeing all state prisons, provides a complex mix of prisoner services-food, clothing, shelter, occupational training, medical care and the likefor prisoners through the department's own facilities and personnel. The primary service of the Department of Public Safety, enforcement of state laws through a network of state police and other law enforcement officers, is also complex. Both departments are large-scale organizations, operate under policies of decentralized administration of formalized rules and regulations, and have large numbers of employees arranged in strict hierarchical patterns of superiors and subordinates.

The political/regulatory environment with which both agencies interact is highly uncertain and subject to considerable constraint at least from time to time in that prisons and law enforcement can become "hot" political topics subject to citizen, legislative and pressure group lobbying in the wake of departmental happenings, such as a prison escape or "cop shooting." which may intrude upon the public conscience.

Th'o-Way' Symmetric Model Dominant.
The two-way symmetric model was dominant for more state agencies than any other model: it best fit the way five agencies described their public relations behavior. Those five agencies and their scores were the Department of Justice (4.50), Labor (3.67), Wildlife and Fisheries (3.83), Education (3.33) and the Governor's Office (2.83).

This model was subordinate, in the Number 2 position, for the Departments of Public Safety and Corrections.

Mean score for all agencies on the twoway symmetric model was 2.92 , and threefourths $(75 \%)$ of the agencies scored above the scale's midpoint. The standard deviation of .67 was the largest of any of the four models, however.

The agencies for which the two-way symmetric model was dominant fit Grunig's model characteristics quite well, although some fit better than others. With the exception of the Department of Education, which operates on a large-scale, they are smaller-scale operations. All perform complex tasks and interact with environments which are high in uncertainty and moderately constrained.

The services and tasks of the five agencies are relatively specialized and narrow in scope, with the possible exception of the Governor's Office, and thus the agencies' activities are accomplished within an organizational structure in which specialists, more than bureaucrats, prevail. The scale of activity is narrowed, but made more complex, by this specialization.

The environments of these agencies are generally uncertain and moderately or highly constrained, primarily because all are the object of at-times intense lobbying by citizens, pressure groups and organizations outside state government. This is most true of the Governor's Office. But the Department of Wildlife and Fisheries also feels pressure from sportsmen every time it considers a change in hunting or fishing regulation; the Department of Education feels pressure from parents and teachers when it debates educational policy; and the Department of Labor likewise feels the squeeze from labor unions on the one hand and the unemployed on the 
other. And of course the Governor's Office is all political, a focal point for outsiders who seek to influence those inside state government.

\section{Discussion}

Through application of Grunig's models of public relations behavior to Louisiana state government agencies, this study provides another look at how organizations manage their communications with their constituent publics. The study in and of itself is descriptive of how public relations practitioners with these state agencies view their function. But it also provides corroboration for several key aspects of Grunig's theories:

1) Each organization does appear to have a dominant public relations "style" for managing its public relations. Each agency had a dominant set of public relations behaviors which best fit the organization's needs more often than any other model.

2) While each organization has a dominant style, that is not to the exclusion of the other models of public relations behavior. Signs of all four models were found in each state agency, depending upon the particular circumstances surrounding a situation which called for communication with the public.

3) Organizationai characteristics and conditions in the organization's environment did seem to influence which public relations model predominated for a particular agency. Scale and complexity of product/service environment and level of uncertainty and constraint in political/ regulatory environment did vary, as Grunig suggested, from model to model.

4) Generally, organizational characteristics of the state agencies correlated well with Grunig's findings from his earlier study of organizations. The characteristics Grunig attributed to organizations for which a particular model was dominant were similar to the characteristics of the Louisiana agencies for which that same model was dominant. This holds true with reasonable reliability for all four of the models examined.

Thus, there was support for all four hypotheses relating to environmental variables as predictors of or influences upon public relations behavior in organizations.

\section{Conclusions}

While the additional empirical evidence generated by this study may be important-evidence that real organizations fit models and typologies of public relations behavior and organizational characteristics-broader research in the future might prove even more fruitful.

The models and the environmental variables which contribute to their adoption deserve further examination in a variety of additional organizational settings, settings broader than the relatively small number of corporations and federal and state agencies examined to date.

And the scope of study merits enlargement to answer additional research questions raised by the findings thus far. For instance, is one model of public relations behavior, and/or a particular type of organization, more effective than another in winning acceptance of its communication messages by key audiences? Do organizations which practice two-way symmetrical public relations, for instance, get better results in influencing the agenda of their audiences than organizations which practice the press agentry/publicity or public information or two-way asymmetric models? Do organizations which practice a particular model of public relations behavior get better results with some audiences, such as the news media, than they do with other audiences such as customers or clients?

One future study suggested by these findings might compare the results of each of the organizational types in placing messages with the same target audience-say the news media-to see if the public relations model used influences message reception and acceptance of the message as part of the media's agenda. Message acceptance and the setting of the media's agenda in such a study might be counted as accomplished if the media published a story based upon an information subsidy supplied in a public relations message such as a news release or press conference. 